Gut, 1964, 5, 173

\title{
The parathyroids, calcium and gastric secretion in man and the dog
}

\author{
J. T. WARD, A. O. ADESOLA, AND R. B. WELBOUR N ${ }^{1}$ \\ From The Queen's University of Belfast, Northern Ireland
}

EDITORIAL SYNOPSIS The possible relationship between hyperparathyroidism and peptic ulcer has stimulated renewed interest in the relationship between calcium and gastric secretion. This study shows that in patients with primary hyperparathyroidism the basal secretion of acid was raised but the augmented histamine secretion was essentially normal. The basal secretion was lowered by parathyroidectomy. Studies in dogs shows a different pattern of gastric secretory response.

A possible relationship between the parathyroid glands and gastric secretion was suggested nearly 50 years ago in experiments with innervated (Pavlov) gastric pouches. Keeton (1914) found that parathyroidectomy reduced secretion in the cat, and Rogers, Rahe, Fawcett, and Hackett (1915) observed that a crude extract of parathyroid tissue caused an increase in secretion in the dog. Several others have studied the problem from time to time, while today many are interested in it because of the recognition that peptic, and especially duodenal, ulceration is a frequent feature of both primary hyperparathyroidism and the syndrome of multiple endocrine adenopathy in man (Welbourn and Ward, 1962).

Many conflicting observations have been reported in man and in several species of animals (Table I). In acute experiments injections of parathormone apparently increase the secretion of acid and of pepsin in man. In certain circumstances they do so in the dog also, but in other circumstances they either diminish secretion or do not influence it. Basal secretion of both acid and pepsin in the rat is diminished. The main difficulty with these studies is that commercial preparations of parathormone are toxic and it is very difficult to give repeated injections to maintain an animal in a state of chronic hyperparathyroidism. Those who have been most successful in doing so (Allen and Elliott, 1961) have found depressed secretion of acid and no effect on that of pepsin in the dog. The few studies of gastric secretion which have been made in human subjects with primary hyperparathyroidism do not reveal any consistent deviation from normal (Ostrow, Blanshard, and Gray, 1960).

${ }^{1}$ Reprints should be requested from R. B. Welbourn, Postgraduate Medical School, Ducane Road, London, W.12.
Parathyroidectomy (partial or total and usually combined with thyroidectomy) has always been found to reduce the secretion of acid and of pepsin in animals, and subsequent injections of calcium salts have restored it (Keeton, 1914; Chang and Sloan, 1927). Here, however, it is difficult to distinguish between the separate influences of the thyroid and the parathyroid glands, even when thyroid substitution therapy is provided, for gastric secretion is reduced by an excess and possibly by a deficiency of thyroxine (Nasset and Goldsmith, 1961). However, in a patient with idiopathic hypoparathyroidism studied very thoroughly by Donegan and Spiro (1960) free acid was completely absent and the concentration of pepsin was very low in the basal juice. An infusion of calcium gluconate and an injection of parathormone both restored secretion rapidly for short periods of time. Prolonged therapy with vitamin $\mathrm{D}$ and calcium maintained the secretion of acid and of pepsin at normal levels. Low concentrations of acid in the gastric juice have also been found in infants with hypocalcaemic tetany and restoration of the serum calcium concentration has increased the acidity (Babbott, Johnston, and Haskins, 1923). In both these studies the critical level of serum calcium, at which gastric secretion was restored, was about 7.0 to $7.5 \mathrm{mg}$. per $100 \mathrm{ml}$. Parathyroidectomy in patients with primary hyperparathyroidism has not been found to produce any consistent change in secretion (Donegan and Spiro, 1960).

The observation that calcium and vitamin $\mathbf{D}$ restore secretion in hypoparathyroidism suggests that parathormone affects gastric secretion by means of its control of the serum calcium. Intravenous injections of calcium salts, which raise the concentra- 
TABLE I

SUMMARY OF MAIN EXPERIMENTAL OBSERVATIONS ON INFLUENCE OF PARATHYROID GLANDS AND CALCIUM ON GASTRIC SECRETION IN NORMAL HUMAN SUBJECTS AND IN ANIMALS (FINDINGS IN HYPER- AND HYPOPARATHYROIDISM IN MAN NOT INCLUDED)

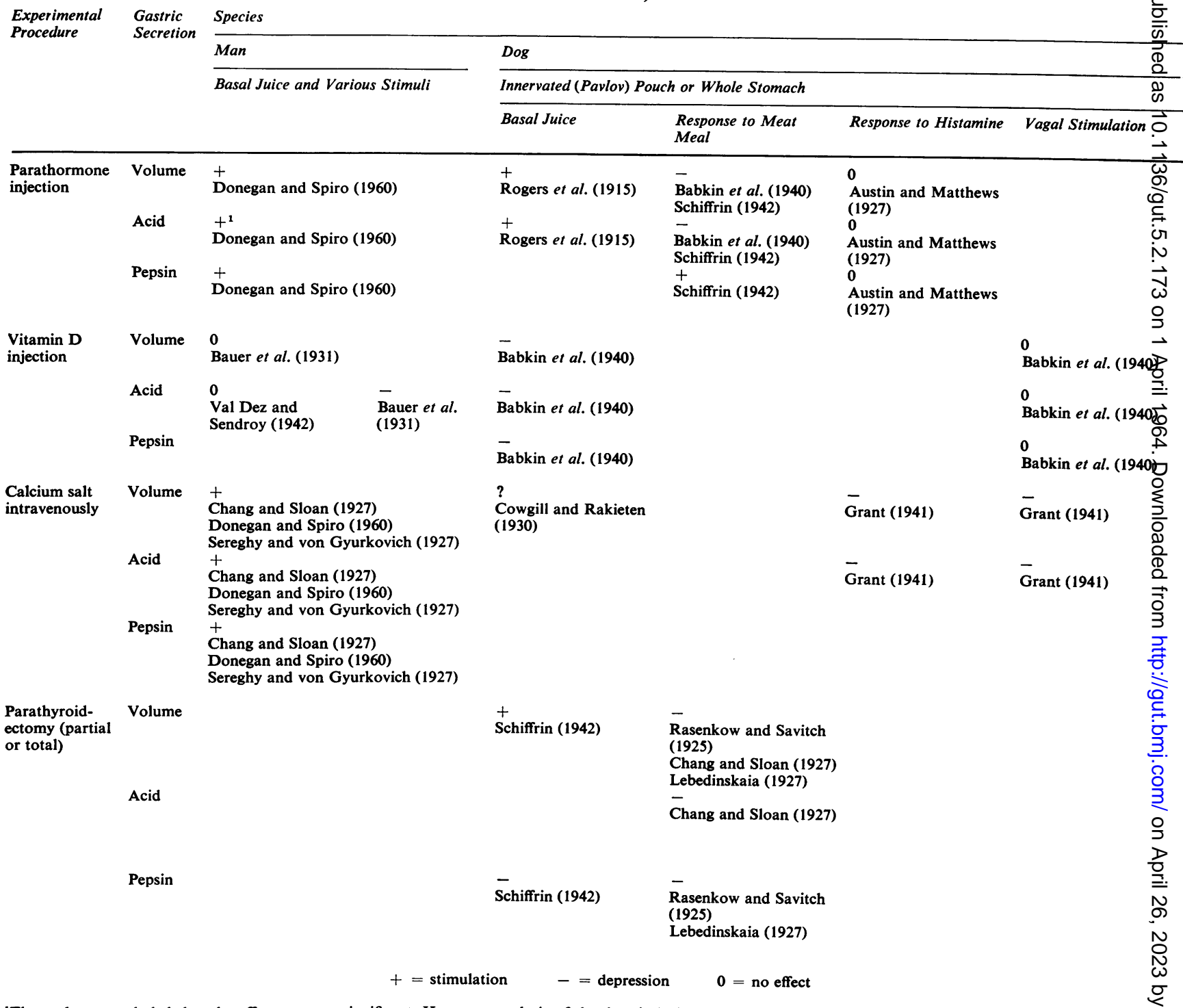

${ }^{1}$ The authors concluded that the effect was not significant. However, analysis of the data in Table 3 of their paper shows that the mean change in concentration 6 of free acid after injection of parathormone was $9.46 \mathrm{mEq}$. per litre [t (paired data) $=3.47 ; \mathrm{D}$ of $\mathrm{F}=12 ; 0.01>P>0.001]$. The mean change in pH was 1.20 units [t (paired data) $=2.09 ; D$ of $F=12 ; 0.1>P>0.05]$.

tion of calcium acutely, have been reported to increase the secretion of acid and of pepsin in man and to reduce that of acid in three species of animals. Injections of calciferol, the effect of which on the serum calcium is slower and more prolonged, have provided conflicting results in man but appear to increase the secretion of acid and possibly of pepsin in the dog. Experimental reduction of the serum calcium by induction of rickets in rats is associated with gastric hyposecretion and therapy with vitamin $D$ restores secretion to normal (Herting and Steenbock, 1955). Frog gastric mucosa, bathed in vitro in solutions of electrolytes, secretes free acid only when the concentration of calcium in the fluid is 
TABLE I-continued

SUMMARY OF MAIN EXPERIMENTAL OBSERVATIONS ON INFLUENCE OF PARATHYROID GLANDS AND CALCIUM ON GASTRIC SECRETION IN NORMAL HUMAN SUBJECTS AND IN ANIMALS (FINDINGS IN HYPER- AND HYPOPARATHYROIDISM IN MAN NOT INCLUDED)

\section{Species}

\begin{tabular}{|c|c|c|}
\hline \multicolumn{3}{|l|}{ Dog } \\
\hline \multicolumn{3}{|c|}{ Separated (Heidenhain) Pouch } \\
\hline 24-hour Juice & & Response to Histamine \\
\hline $\begin{array}{l}+ \\
\text { Babkin et al. (1940) } \\
\text { Schiffrin (1942) } \\
+ \\
\text { Babkin } \text { et al. (1940) } \\
\text { Schiffrin (1942) } \\
0 \\
\text { Schiffrin (1942) } \\
\text { Allen and Elliott (19) } \\
+ \\
\text { Babkin et al. (1940), } \\
\text { Neely and Goldman } \\
+ \\
\text { Babkin } \text { et al. (1940), } \\
\text { Neely and Goldman } \\
- \\
\text { Neely and Goldman }\end{array}$ & $\begin{array}{l}\text { Allen and Elliott } \\
\text { (1961) } \\
- \\
\text { Allen and Elliott } \\
\text { (1961) } \\
61) \\
\text { Schiffrin (1942), } \\
\text { (1962) } \\
\text { Schiffrin (1942), } \\
\text { (1962) } \\
\text { (1962) }\end{array}$ & $\begin{array}{l}\text { Allen and Elliott (1961) } \\
\text { Allen and Elliott (1961) } \\
0 \\
\text { Allen and Elliott (1961) }\end{array}$ \\
\hline
\end{tabular}

\begin{tabular}{|c|c|c|}
\hline Cat & Rat & Pigeon \\
\hline Innervated Pouch & $\begin{array}{l}\text { Pylorus Ligation } \\
\text { (Shay preparation) }\end{array}$ & Response to Histamine \\
\hline
\end{tabular}

o

Blanshard et al. (1959)

0

Blanshard et al. (1959)

0

Blanshard et al. (1959)
Gastric Experimental Secretion Procedure
Volume

Parathormone injection

Acid

Pepsin

Pepsin

Mahfouz and

Mahfouz and Koskowski (1959)
Mahfouz and Koskowski (1959)

Mahfouz and Koskowski (1959)

Volume

Vitamin D injection

Acid

Pepsin

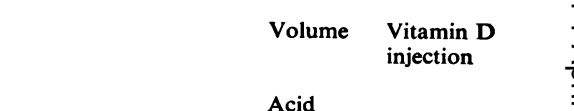

Volume Calcium salt intravenously

Acid

(1)

Pepsin

Volume

Parathyroidectomy (partial or total) between 5 and $10 \mathrm{mg}$. per $100 \mathrm{ml}$. (Gray and Adkison, 1941).

A variety of structural changes have been observed in the stomach in animals after these experimental procedures. Acute superficial ulceration may follow both injections of parathormone (Lehr, Wajda, and Krukowski, 1958; Blanshard, Arabehety, and Gray,
1959) and partial parathyroidectomy (Friedman, 1918), but chronic peptic ulceration has not been observed. Hyperaemia of the mucosa and haemorrhage and deposition of calcium in the gastric glands follow the injection of large doses of parathormone in dogs (Collip, 1926; Hueper, 1927; Cantarow, Stewart, and Housel, 1938; Rutishauser and 
Majno, 1953), but are not caused by small doses (Babkin, Komarov, and Komarov, 1940; McJunkin, Tweedy, and Breuhaus, 1932). Hyperplasia of the chief cells (which secrete pepsin) has been observed after injections of parathormone and of vitamin $D$ in rabbits and rats (Lewinter and Spiro, 1960) and hyperplasia of all the glandular elements (associated with hypersecretion of acid and of pepsin) has been reported after the administration of vitamin $\mathrm{D}$ in a dog (Neely and Goldman, 1962). The significance of these observations is uncertain.

There are clearly many problems which require further investigation. We have studied gastric secretion of acid in the following circumstances: In man, in primary hyperparathyroidism and after parathyroidectomy; in dogs with separated (Heidenhain) pouches, 1 after elevation of the serum calcium by injection of parathormone and of vitamin $D$ and by infusion of calcium salt, and 2 after depression of the serum calcium by infusion of edathamil and by parathyroidectomy.

\section{PATIENTS, MATERIALS, AND METHODS}

In man the secretion of gastric acid was measured in nine patients with primary hyperparathyroidism about one week before parathyroidectomy and again two to eight months after operation. Two further patients, whose necks were explored without parathyroid disease being confirmed, served as controls. The patients were allowed to swallow their saliva and the aspirations were made continuously by hand. Measurements were made of (1) the basal juice secreted during one hour after an overnight fast of 12 hours and (2) the augmented histamine secretion (Kay, 1953). The volume of each specimen was measured and its total acid content (in mEq.) estimated by titration against $\mathrm{N} / 10$ or $\mathrm{N} / 20$ $\mathrm{NaOH}$ with phenolphthalein.

In the animal experiments 22 mongrel bitches weighing 6 to $20 \mathrm{~kg}$. were used. Separated (Heidenhain) pouches were prepared and fitted with Duralumin cannulae. Control studies of gastric secretion were started four or more weeks after operation and experiments were undertaken only when the secretion had become stabilized. Further control studies were made at frequent intervals between the experiments. The animals were fed a standard diet which had been found, in this laboratory, to maintain a healthy state and a constant weight. It consisted of meat offal and pig starter meal in equal parts, and sufficient to provide about 70 Calories per $\mathrm{kg}$. of body weight was fed once daily. The dogs were fasted for 18 hours before all secretory tests.

The various preparations designed to raise or lower the serum calcium were administered as follows:

PARATHORMONE (Eli Lilly) This was given in two ways. 1 It was hoped that, by giving daily subcutaneous injections, the serum calcium would be raised within a day or two by 2 to $4 \mathrm{mg}$. per $100 \mathrm{ml}$. and that a state of chronic hyperparathyroidism would be induced. The initial dose of 18 U.S.P. units per kilogram of body weight per day in one dog raised the level (24 hours after the last injection) by only $2.0 \mathrm{mg}$. in six days. Higher doses of 20 to 38 units per kilogram per day increased it by 3 to $6 \mathrm{mg}$. per $100 \mathrm{ml}$. in three to seven days in each of five dogs. Thereafter the levels fell again, even though injections of parathormone were continued. Parathormone was given for five to 11 days, and then had to be stopped in all animals because of the development of severe anorexia, lassitude, and loss of weight. Death resulted (or the animals had to be killed) in seven to 57 days. This method of administration was therefore abandoned. 2 Single subcutaneous injections of parathormone ( 20 units per $\mathrm{kg}$.) were given to eight dogs which were then studied intensively for 16 to 36 hours. The serum calcium rose by 2 to $5 \mathrm{mg}$. per $100 \mathrm{ml}$., reaching its peak value 13 to 20 hours after injection and returning to normal after about 36 hours. No toxic effects were observed.

VITAMIN D Calciferol B.P. was given to four dogs, by subcutaneous injection, in a daily dose of $10 \mathrm{mg}$. ( 400,000 i.u.) until the serum calcium level had risen by 2 to $3 \mathrm{mg}$. per $100 \mathrm{ml}$. In one dog the dose was increased to $15 \mathrm{mg}$. per day after nine days because the serum calcium level had not started to rise. These doses represented 26,000 to 43,000 i.u. per kg. per day. Injections were usually given for two to three weeks, after which time the serum calcium level rose further and fluctuated at a high level. The peak values ranged from 16.6 to $19.6 \mathrm{mg}$. per $100 \mathrm{ml}$. Three of the dogs became anorexic and all four lost weight steadily and died or were killed in two to 15 weeks, while the serum calcium levels were still elevated. (A fifth dog, which is not included, died within one week without being studied.)

CALCIUM LACTATE This was prepared in a fresh $5 \%$ solution in water and injected intravenously. A single dose of $13 \mathrm{mg}$. of calcium per kilogram of body weight was given in each test. The serum calcium rose immediately by 1 to $5 \mathrm{mg}$. per $100 \mathrm{ml}$. and returned to normal in three to four hours in each of 10 tests in six dogs.

EDATHAMIL (DI-SODIUM SALT OF DIAMINOETHANE TETRAACETIC ACID) Edathamil, a chelating agent, was given with the object of lowering the serum calcium level. A fresh $2 \%$ solution was prepared in physiological saline and adjusted to $p \mathrm{H} 7.4$ with dilute $\mathrm{NaOH}$. The solution was given by continuous intravenous infusion in a dose calculated to lower the serum calcium by 2 to $5 \mathrm{mg}$. per $100 \mathrm{ml}$. for about one hour (Braun, Horne, Bettinger, and Bellet, 1955). The dose was $2.5 \mathrm{mg}$. per $\mathrm{kg}$. of body weight for the first 45 minutes and $1.25 \mathrm{mg}$. per $\mathrm{kg}$. for the next hour. During this hour the serum calcium was in fact lowered by 3 to $5 \mathrm{mg}$. per $100 \mathrm{ml}$. in each of nine experiments in seven dogs.

Three dogs were subjected to surgical thyroparathyroidectomy and were then fed $0.025 \mathrm{mg}$. of 1 -thyroxine sodium per day to maintain a euthyroid state. Tetany was controlled initially by intravenous calcium lactate as required and then by the addition of milk and calcium lactate to the diet. The serum calcium level became 
stabilized at 5 to $8 \mathrm{mg}$. per $100 \mathrm{ml}$., without overt tetany, about two to three weeks after operation. Secretory tests were then performed.

SERUM CALCIUM ESTIMATIONS These were made frequently and were always done in duplicate. At first a modified Tisdall method was used (Clark and Collip, 1925). Later estimations were made by titration against sodium edetate, with calcein-thymol-phthalein indicator, under a Wood's ultra-violet lamp (Baron and Bell, 1957). The two methods gave closely similar results in our hands. We preferred the latter because of the speed with which the results could be obtained.

COLLECTION OF GASTRIC JUICE Gastric juice was collected in graduated tubes and the following estimations were made: Volume, by direct measurement; $p \mathrm{H}$, by a direct reading $p \mathrm{H}$ meter; and free and total acid by titration against $\mathrm{N} / 10$ or $\mathrm{N} / 20 \mathrm{NaOH}$ with Töpfer's reagent and phenolphthalein as indicators.

Collections were made under basal conditions for periods of one to eight hours and after stimulation with histamine in two ways:

1 Standard histamine test Histamine acid phosphate $(0.36 \mathrm{mg}$. histamine base per $10 \mathrm{~kg}$. body weight) was injected subcutaneously and 15 minutes later gastric secretion was collected for half an hour.

2 Histamine infusion test A constant dose of histamine was infused intravenously throughout the test in a dose which had been found to stimulate 30 to $40 \%$ of the maximal acid output (Code, Blackburn, Livermore, and Ratke, 1949).

\section{RESULTS}

IN MAN The mean normal basal secretion of total acid in our laboratory is 1.23 (S.D. 1.67) $\mathrm{mEq}$. per hour and is about the same for men and for women. The figures reported by Baron (1963) are very similar. The upper limit of normal (defined as mean +3 S.D.) is $5.3 \mathrm{mEq}$. per hour. Before operation five of the nine patients with primary hyperparathyroidism secreted at levels higher than this (Table II). We have no control figures for total acid in the augmented histamine test, but Baron's means are $10 \cdot 8$ (S.D. 12.9) $\mathrm{mEq}$. per half hour for men and $6 \cdot 1$ (S.D. 4.5) mEq. per half hour for women. The hyperparathyroid patients all secreted within his normal ranges, although the mean values were raised slightly.

Parathyroidectomy reduced the basal secretion by an average of $38 \%$. After operation the basal secretion fell in all but one patient (in whom it was very low initially) and all but one secreted within the normal range. Operation tended to reduce the augmented histamine secretion, but the mean fall of $34 \%$ was not significant. It did not increase the secretion in any patient.

Secretion in the two patients whose necks were explored with negative findings was normal before operation and did not change appreciably afterwards.

The five patients with hyperparathyroidism, whose basal secretion was greater than normal, had alimentary symptoms. One of the males (case 2) had a duodenal ulcer, which was not relieved by parathyroidectomy. One (case 3 ) had a prepyloric ulcer with vomiting and one (case 1) ulcer-like symptoms but no definite lesion. Operation relieved the

T ABLE I I

INFLUENCE OF PARATHYROIDECTOMY ON GASTRIC ACID SECRETION IN PATIENTS WITH PRIMARY HYPERPARATHYROIDISM

\begin{tabular}{|c|c|c|c|c|c|c|c|c|}
\hline \multirow[t]{2}{*}{ Patient } & \multicolumn{2}{|c|}{$\begin{array}{l}\text { Range of Serum Calcium } \\
(\mathrm{mg} . / 100 \mathrm{ml} .)\end{array}$} & \multicolumn{3}{|c|}{ Basal ( $m E q$. total acid in one hour) } & \multicolumn{3}{|c|}{$\begin{array}{l}\text { Augmented Histamine ( } m E q \\
\text { hour) }\end{array}$} \\
\hline & $\begin{array}{l}\text { Pre-operatively } \\
\text { rathyroidism }\end{array}$ & $\begin{array}{l}\text { Post- } \\
\text { operatively }\end{array}$ & Pre-operatively & $\begin{array}{l}\text { Post- } \\
\text { operatively }\end{array}$ & Change & Pre-operatively & $\begin{array}{l}\text { Post- } \\
\text { operatively }\end{array}$ & Change \\
\hline \multicolumn{9}{|l|}{ Males } \\
\hline 1 & $10 \cdot 0-12 \cdot 0$ & $10 \cdot 4-10 \cdot 7$ & $7 \cdot 5$ & $4 \cdot 6$ & $-2.9(-39 \%)$ & $8 \cdot 7$ & $6 \cdot 1$ & $-2 \cdot 6(-30 \%)$ \\
\hline 2 & $11 \cdot 1-12 \cdot 6$ & $10 \cdot 0-10 \cdot 7$ & $7 \cdot 0$ & 4.5 & $-2.5(-36 \%)$ & $12 \cdot 7$ & $12 \cdot 7$ & $(0 \%)$ \\
\hline 3 & $13 \cdot 5-18 \cdot 3$ & $6 \cdot 2-10 \cdot 9$ & 6.9 & 1.0 & $-5.9(-86 \%)$ & $22 \cdot 5$ & $5 \cdot 7$ & $-16.8(-75 \%)$ \\
\hline 4 & $10 \cdot 2-11 \cdot 4$ & $9 \cdot 6-10 \cdot 3$ & $4 \cdot 3$ & $3 \cdot 5$ & $-0.8(-19 \%)$ & $9 \cdot 0$ & $6 \cdot 4$ & $-2.6(-29 \%)$ \\
\hline 5 & $10 \cdot 5-12 \cdot 0$ & $9 \cdot 9-10 \cdot 8$ & $2 \cdot 9$ & 0.0 & $-2.9(-100 \%)$ & $7 \cdot 7$ & $7 \cdot 3$ & $-0.4(-5 \%)$ \\
\hline Mean & & & $5 \cdot 7$ & $2 \cdot 7$ & $-3.0(-56 \%)$ & $12 \cdot 1$ & $7 \cdot 6$ & $-4.5(-28 \%)$ \\
\hline \multicolumn{9}{|l|}{ Females } \\
\hline 1 & $11 \cdot 6-12 \cdot 6$ & $9 \cdot 7-10 \cdot 7$ & $6 \cdot 2$ & $5 \cdot 5$ & $-0.7(-11 \%)$ & $18 \cdot 5$ & $17 \cdot 6$ & $-0.9(-5 \%)$ \\
\hline 2 & $11 \cdot 2-13 \cdot 1$ & $9 \cdot 1-10 \cdot 5$ & 6.0 & 4.7 & $-1 \cdot 3(-22 \%)$ & $7 \cdot 6$ & $7 \cdot 1$ & $-0.5(-7 \%)$ \\
\hline 3 & $11 \cdot 3-11 \cdot 8$ & $9 \cdot 6-10 \cdot 0$ & $0 \cdot 4$ & 0.0 & $-0.4(-100 \%)$ & 0.5 & 0.0 & $-0.5(-100 \%)$ \\
\hline 4 & $13 \cdot 0$ & $9 \cdot 4-9 \cdot 7$ & 0.6 & 1.0 & $+0.4(+67 \%)$ & 7.9 & $3 \cdot 4$ & $-4.5(-57 \%)$ \\
\hline Mean & & & $3 \cdot 3$ & $2 \cdot 8$ & $-0.5(-16 \%)$ & $8 \cdot 6$ & $7 \cdot 0$ & $-1.6(-42 \%)$ \\
\hline Mean (N & $\mathbf{I}+\mathrm{F})$ & & 4.64 & 2.76 & $-1.9(-38 \%)$ & $10 \cdot 6$ & $7 \cdot 4$ & $-3.2(-34 \%)$ \\
\hline \multicolumn{9}{|c|}{ Negative Exploration on Neck (Males) } \\
\hline 1 & $10 \cdot 3-11 \cdot 5$ & $9 \cdot 3-10 \cdot 6$ & 3.9 & $4 \cdot 0$ & $+0.1(+3 \%)$ & $20 \cdot 0$ & $21 \cdot 0$ & $+1.0(+5 \%)$ \\
\hline 2 & $11 \cdot 0$ & $10 \cdot 9$ & $1 \cdot 7$ & 1.7 & $0.0(0 \%)$ & $3 \cdot 6$ & $3 \cdot 8$ & $+0.2(+6 \%)$ \\
\hline Mean & & & $2 \cdot 8$ & $2 \cdot 8$ & $+0.05(+1.5 \%)$ & $11 \cdot 8$ & $12 \cdot 4$ & $+0.6(+5 \%)$ \\
\hline
\end{tabular}

Statistical Analyses (Hyperparathyroidism, $M+F$ )

Basal: $\quad t$ (paired data) $=2.97 ; \quad D$ of $F=8 ; 0.02>\mathbf{P}>0.05$

Augmented histamine: $t$ (paired data) $=1.81 ; \quad D$ of $F=8 ; 0.2>P>0.1$ 
symptoms in both. One of the females (case 1) had ulcer-like symptoms and one (case 2) had epigastric pain; neither was relieved by parathyroidectomy. The other four patients and the two whose necks were explored with negative findings did not have alimentary symptoms.

IN THE DOG Serum calcium estimations were made many times on all the dogs under control conditions. The average of the means for the 22 dogs was 11.0 (S.D. 0.27$) \mathrm{mg}$. per $100 \mathrm{ml}$. The range of the individual means was 9.6 to 12.4 and the total range of all control readings was 9.3 to $13.2 \mathrm{mg}$. per $100 \mathrm{ml}$.

Basal juice was collected frequently from all dogs under control conditions. The mean $p \mathrm{H}$ in 246 observations was 6.85 and the distribution was as follows:

\begin{tabular}{lc}
$\mathrm{p} H$ & No. of Readings \\
\hline $1 \cdot 1-2 \cdot 0$ & 1 \\
$2 \cdot 1-3 \cdot 0$ & 0 \\
$3 \cdot 1-4 \cdot 0$ & 8 \\
$4 \cdot 1-5 \cdot 0$ & 12 \\
$5 \cdot 1-6 \cdot 0$ & 45 \\
$6 \cdot 1-7 \cdot 0$ & 41 \\
$7 \cdot 1-8 \cdot 0$ & 105 \\
$8 \cdot 1-9 \cdot 0$ & 34 \\
Total & 246
\end{tabular}

The two lowest $p \mathrm{H}$ readings were 1.4 and 3.5 and in these two specimens only (less than $1 \%$ of the control basal readings) was 'free acid' found by titration.

The following two criteria were taken as evidence of stimulation of acid secretion in basal juice: 1 Significant $(\mathrm{P}<0.05)$ reduction in mean $p \mathrm{H}$, and 2 , the appearance of free acid ( $p \mathrm{H} 3.5$ or less) in the basal juice on more than one occasion. 'Free acid' may not have any basic significance (Bock, 1962), but its presence is a useful indication that the $p \mathrm{H}$ is approaching the region in which appreciable peptic activity occurs.

A third criterion of stimulation (or of depression),

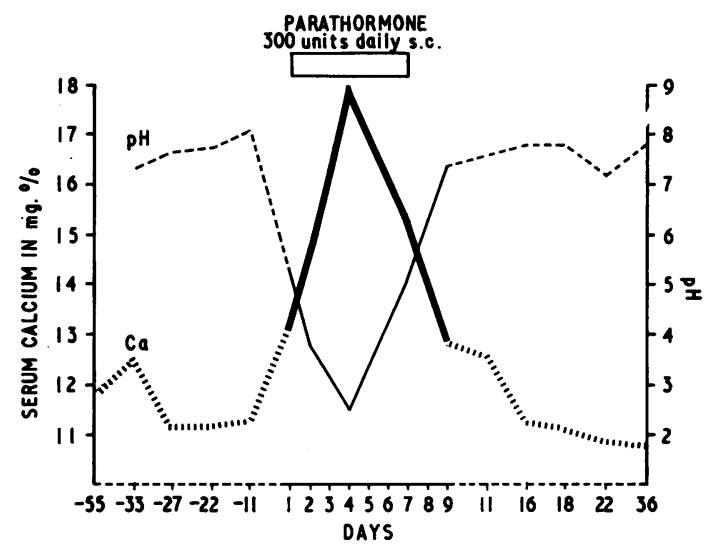

FIG. 1. Influence of daily injections of parathormone on serum calcium and $\mathrm{pH}$ of basal gastric juice (dog 31/60).

employed in the study of histamine-stimulated juice, was a significant change in the output of total acid.

\section{ELEVATION OF SERUM CALCIUM LEVEL}

DAILY INJECTIONS OF PARATHORMONE (FIVE DOGS) Basal gastric juice was collected for periods of four hours on several days before, during, and after the administration of parathormone. In three dogs (Table III and Fig. 1) the mean $p \mathrm{H}$ fell by more than 2 units and free acid was secreted on 50 to $75 \%$ of the days during which parathormone was being given. The response was maximal three to five days after the first injection. The serum calcium levels at these times varied from 12.1 to $17.9 \mathrm{mg}$. per $100 \mathrm{ml}$., values which represented increases of 0.9 to $6.2 \mathrm{mg}$. per $100 \mathrm{ml}$. above the control readings. Maximal secretion occurred in two dogs when the serum calcium was at its peak and in one while the level was rising. The volume of the basal juice was not affected by parathormone and the total amount of free acid secreted was small (maximum $0.1 \mathrm{mEq}$./

\section{TABLE III}

EFFECT OF DAILY INJECTIONS OF PARATHORMONE ON $p H$ OF BASAL GASTRIC JUICE

\begin{tabular}{|c|c|c|c|c|c|c|c|c|c|}
\hline \multirow[t]{2}{*}{ Dog } & \multicolumn{2}{|c|}{ No. of Observations } & \multicolumn{3}{|c|}{ Mean $\mathrm{p} H$} & \multicolumn{2}{|c|}{ Lowest $\mathrm{p} H$} & \multicolumn{2}{|c|}{$\begin{array}{l}\text { Proportion of Days on } \\
\text { which Free Acid Found } \\
(\%)\end{array}$} \\
\hline & Control & $\begin{array}{l}\text { Para- } \\
\text { thormone }\end{array}$ & Control & $\begin{array}{l}\text { Para- } \\
\text { thormone }\end{array}$ & Change & Control & $\begin{array}{l}\text { Para- } \\
\text { thormone }\end{array}$ & Control & $\begin{array}{l}\text { Para- } \\
\text { thormone }\end{array}$ \\
\hline $\begin{array}{l}\text { A/51 } \\
31 / 60 \\
35 / 60 \\
45 / 60 \\
49 / 60 \\
\text { Mean of all days }\end{array}$ & $\begin{array}{l}6 \\
4 \\
8 \\
7 \\
6\end{array}$ & $\begin{array}{l}4 \\
3 \\
5 \\
3 \\
4\end{array}$ & $\begin{array}{l}6 \cdot 6 \\
7 \cdot 7 \\
6 \cdot 3 \\
7 \cdot 5 \\
6 \cdot 4 \\
6 \cdot 9 \\
\text { Mean c }\end{array}$ & $\begin{array}{c}4 \cdot 1 \\
3.8 \\
6.8 \\
7 \cdot 6 \\
4 \cdot 3 \\
5 \cdot 3 \\
\text { e in } p \mathrm{H} \text { no }\end{array}$ & $\begin{array}{l}-2.5 \\
-3.9 \\
+0.5 \\
+0.1 \\
-2 \cdot 1 \\
-1 \cdot 6 \\
\text { statistical }\end{array}$ & $\begin{array}{r}4.7 \\
7.4 \\
5.3 \\
7 \cdot 1 \\
5.5 \\
\\
\text { gnificant }\end{array}$ & $\begin{array}{l}1.3 \\
2.6 \\
5.9 \\
7.4 \\
3.2\end{array}$ & $\begin{array}{l}0 \\
0 \\
0 \\
0 \\
0 \\
0\end{array}$ & $\begin{array}{r}50 \\
67 \\
0 \\
0 \\
75 \\
38\end{array}$ \\
\hline
\end{tabular}


hour). The $p \mathrm{H}$ rose again to normal levels after the injections had been stopped. In the remaining two dogs similar increases in the serum calcium levels were not accompanied by any fall in the $p \mathrm{H}$ of the gastric juice.

Standard histamine tests, performed before and during the administration of parathormone, showed no significant alterations in the secretion of total acid (Table IV).

\section{TABLE IV}

EFFECT OF DAILY INJECTIONS OF PARATHORMONE ON SECRETION OF ACID IN RESPONSE TO SINGLE INJECTIONS OF HISTAMINE

\begin{tabular}{|c|c|c|c|c|c|}
\hline \multirow[t]{2}{*}{ Dog } & \multicolumn{2}{|c|}{ No. of Observations } & \multicolumn{3}{|c|}{$\begin{array}{l}\text { Mean Total Acid (mEq.) per } \\
\text { Half Hour }\end{array}$} \\
\hline & Control & Parathormone & Control & Parathormone & Change \\
\hline $\begin{array}{l}A / 51 \\
31 / 60 \\
35 / 60 \\
45 / 60 \\
49 / 60 \\
\text { Mean of } \\
\text { all dogs }\end{array}$ & $\begin{array}{r}9 \\
4 \\
6 \\
6 \\
11\end{array}$ & $\begin{array}{l}4 \\
4 \\
5 \\
3 \\
3\end{array}$ & $\begin{array}{l}0.7 \\
1.3 \\
0.6 \\
0.9 \\
0.5 \\
0.80\end{array}$ & $\begin{array}{l}0.9 \\
1.2 \\
0.9 \\
0.9 \\
0.4\end{array}$ & $\begin{array}{r}+0.2 \\
-0.1 \\
+0.3 \\
0.0 \\
-0.1 \\
+0.06\end{array}$ \\
\hline
\end{tabular}

Mean change in total acid not statistically significant.

SINGLE INJECTIONS OF PARATHORMONE (EIGHT DOGS) After the injections basal gastric juice was collected during every third hour for 36 hours in one dog and similarly for 24 hours in four dogs. In two others it was collected continuously from the seventh to the sixteenth hours and in one from the seventh to the twenty-third hour.

In two dogs free acid was secreted during each of two tests. In one, juice at a $p \mathrm{H}$ of $2 \cdot 2$ was found after 18 hours on one occasion and at a $p \mathrm{H}$ of 2.8 after 21 hours on another. In the other dog, juice at a $p \mathrm{H}$ of 1.4 (Fig. 2) appeared after 10 hours in one test and at a $p \mathrm{H}$ of 2.9 after 13 hours in another. The lowest $p \mathrm{H}$ readings recorded in these dogs under control conditions were 5.8 and 3.8 respectively. In the first dog the serum calcium was $16.0 \mathrm{mg}$. per $100 \mathrm{ml}$. on both occasions when free acid was secreted. In the first test this represented the peak value, while in the second the peak $(18.0 \mathrm{mg} . / 100 \mathrm{ml}$.) had been passed. In the second dog secretion occurred when the serum calcium levels were 11.6 and $13.9 \mathrm{mg}$. per $100 \mathrm{ml}$. Peak levels of 12.7 and $14 \cdot 1 \mathrm{mg}$. per $100 \mathrm{ml}$. respectively were found later. The volume of juice was not affected by parathormone.

In the remaining six dogs parathormone did not influence the secretion of basal juice during the period of study, but in two of these the secretion was collected for 16 hours only.

DAILY INJECTIONS OF VITAMIN D (FOUR DOGS) Basal secretion (Table V and Fig. 3) was collected twice

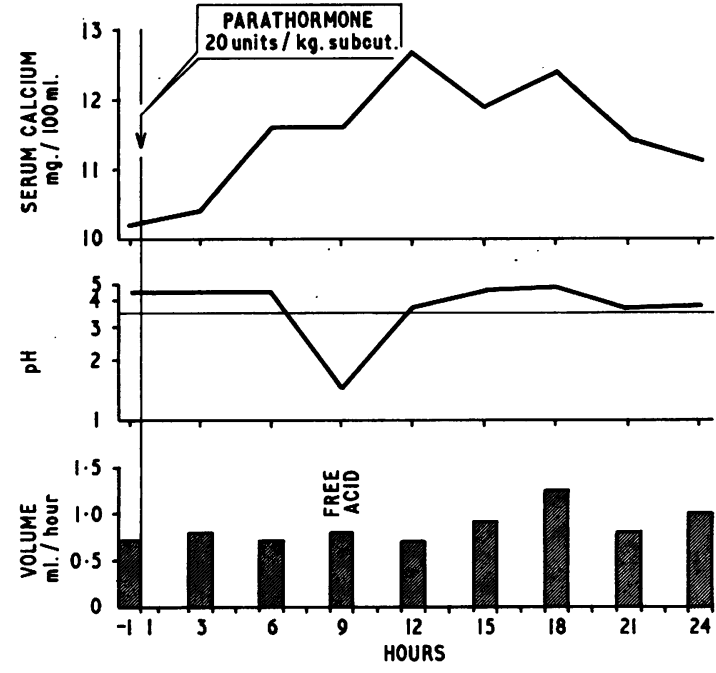

FIG. 2. Influence of single injection of parathormone on serum calcium and on $\mathrm{pH}$ and volume of basal gastric juice (dog 3/62).

weekly for periods of four hours from the time the serum calcium level exceeded the highest control reading until death. The mean volume for all the dogs was not affected significantly, although the individual means were increased in three dogs. The mean $p \mathrm{H}$ fell appreciably in all and free acid was secreted, on the average, on $22 \%$ of the days.

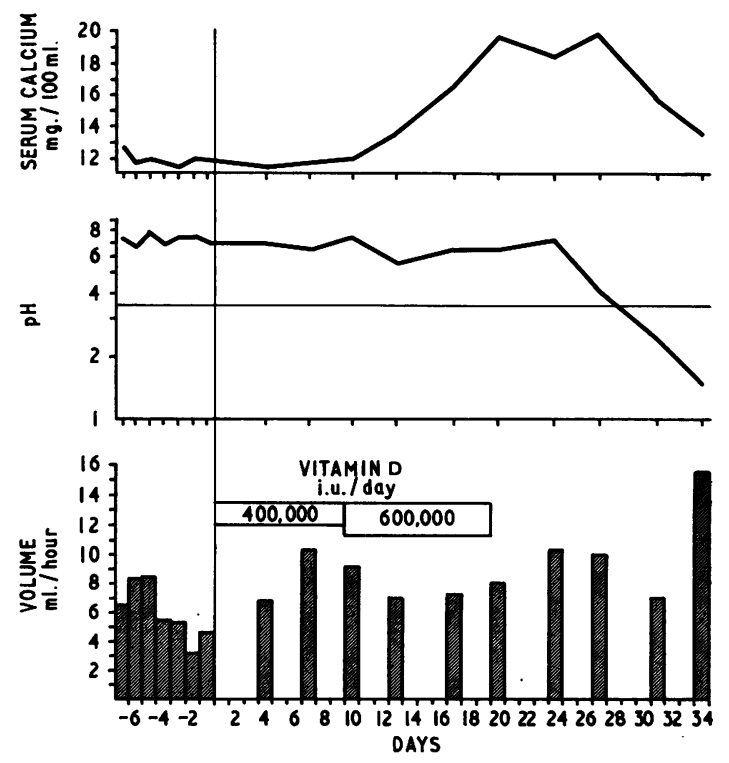

FIG. 3. Influence of daily injections of vitamin $D$ on serum calcium and on $\mathrm{pH}$ and volume of basal gastric juice (dog 40/61). 
TABLE V

EFFECT OF VITAMIN D ON VOLUME AND $p$ H OF BASAL GASTRIC JUICE Dog No. of Observations Mean Volume (ml.) per Four Hours pH

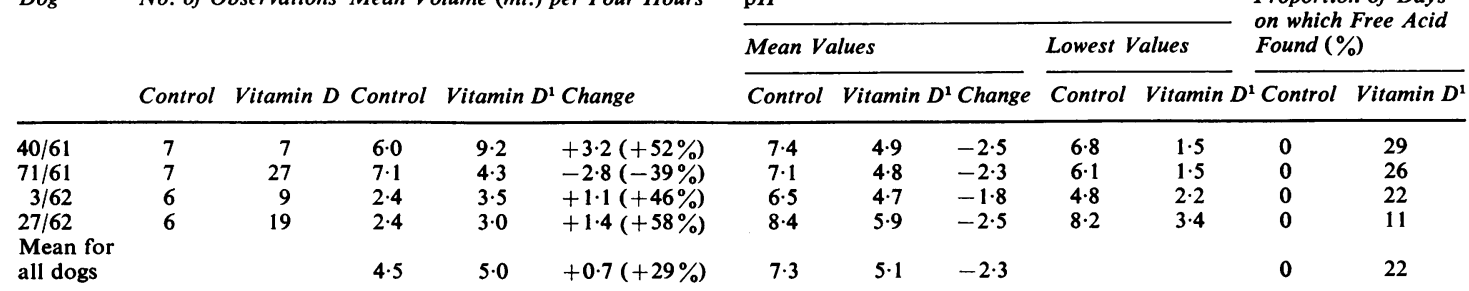

After serum calcium exceeded highest control value.

Statistical Analyses

Volume $\quad t$ (paired data) $=0.56 ; \mathrm{D}$ of $\mathrm{F}=3 ; 0.7>\mathrm{P}>0.6$

Mean $p \mathrm{H} \quad \mathrm{t}$ (paired data) $=13.54 ; \mathrm{D}$ of $\mathrm{F}=3 ; \mathrm{P}<0.001$

TABLE VI

EFFECT OF VITAMIN D ON VOLUME AND TOTAL ACID OF GASTRIC JUICE SECRETED IN RESPONSE TO SINGLE INJECTIONS OF HISTAMINE

\begin{tabular}{|c|c|c|c|c|c|c|c|c|}
\hline \multirow[t]{2}{*}{ Dog } & \multicolumn{2}{|c|}{ No. of Observations } & \multicolumn{3}{|c|}{ Mean Volume (ml.) per Half Hour } & \multicolumn{3}{|c|}{ Mean Total Acid (mEq.) per Half Hour } \\
\hline & Control & Vitamin $D$ & Control & Vitamin $D$ & Change & Control & Vitamin $D$ & Change \\
\hline $\begin{array}{r}40 / 61 \\
71 / 61 \\
3 / 62 \\
27 / 62 \\
\text { Mean }\end{array}$ & $\begin{array}{l}6 \\
5 \\
6 \\
5\end{array}$ & $\begin{array}{r}7 \\
27 \\
9 \\
17\end{array}$ & $\begin{array}{l}9 \cdot 8 \\
1 \cdot 8 \\
7 \cdot 5 \\
4 \cdot 8 \\
6 \cdot 0\end{array}$ & $\begin{array}{l}9 \cdot 3 \\
1 \cdot 8 \\
5 \cdot 8 \\
2 \cdot 4 \\
4 \cdot 8\end{array}$ & $\begin{array}{c}-0.5(-5 \%) \\
0.0(0 \%) \\
-1.7(-23 \%) \\
-2.4(-50 \%) \\
-1.1(-19 \%)\end{array}$ & $\begin{array}{l}1 \cdot 37 \\
0 \cdot 15 \\
0.85 \\
0 \cdot 60 \\
0.75\end{array}$ & $\begin{array}{l}1 \cdot 20 \\
0 \cdot 18 \\
0 \cdot 74 \\
0 \cdot 27 \\
0 \cdot 33\end{array}$ & $\begin{array}{l}-0.17(-12 \%) \\
+0.03(+20 \%) \\
-0.11(-13 \%) \\
-0.33(-55 \%) \\
-0.14(-15 \%)\end{array}$ \\
\hline $\begin{array}{l}\text { Statistical } \\
\text { Volume } \\
\text { Total acid }\end{array}$ & $\begin{array}{l}\text { alyses } \\
\text { t (paired } \\
t \text { (paired }\end{array}$ & $\begin{array}{l}\text { ta })=2.10 \\
\text { ta) }=1.95\end{array}$ & $\begin{array}{l}\text { f } F=3 \\
\text { f } F=3\end{array}$ & $\begin{array}{l}2>P>0.1 \\
3>P>0.2\end{array}$ & & & & \\
\hline
\end{tabular}

Standard histamine tests (Table VI) were performed immediately after most of the collections of basal juice. The mean volume of the juice and the secretion of total acid were reduced in three of the animals and affected little, if at all, in the fourth. The change was not technically significant.

SINGLE INTRAVENOUS INJECTIONS OF CALCIUM Basal secretion (six dogs) was collected for two to five hours before and for two and a half to five hours after injection of calcium. The volume fell after injection in every dog, immediately in four and after 30 minutes in two. The volume remained low for one to four and a half hours. The mean inhibition in the two hours immediately following the injection of calcium compared with the two hours immediately before was $42 \%$ (Table VII). There was no consistent change in $p \mathrm{H}$ and free acid was not secreted.

A histamine infusion test was performed on four dogs. Histamine was infused for one and a half to three hours before the injection of calcium and for one and a half to five hours after. Gastric juice was collected continuously and samples were taken every 15 minutes. The volume and acid fell in every case after injection of calcium (Table VIII). The mean fall in the hour immediately following the injection compared with the hour immediately before was not,

\section{TABLE VII}

EFFECT OF INTRAVENOUS CALCIUM LACTATE ON VOLUME OF BASAL GASTRIC JUICE

\begin{tabular}{lccc}
\multirow{2}{*}{ Dog } & \multicolumn{2}{c}{ Volume of Juice $(\mathrm{ml}$.$) in Two Hours$} & Change in Volume $(\mathrm{ml})$. \\
\cline { 2 - 3 } & Before Calcium & After Calcium & \\
\hline $14 / 61$ & 2.4 & 0.9 & $-1.5(62 \%)$ \\
$40 / 61$ & 2.8 & 1.9 & $-0.9(32 \%)$ \\
$42 / 61$ & 3.1 & 1.3 & $-1.8(58 \%)$ \\
$51 / 61$ & 6.1 & 4.8 & $-1.3(21 \%)$ \\
$53 / 61$ & 2.9 & 1.8 & $-1.1(38 \%)$ \\
$54 / 61$ & 5.4 & 3.2 & $-2.2(41 \%)$ \\
Mean & 3.8 & 2.3 & $-1.5(42 \%)$ \\
Statistical Analysis & & \\
t (paired data) $=7.32 ; \quad$ D of F $=5 ; \quad P<0.001$
\end{tabular}

however, technically significant because the range of individual results was great.

\section{DEPRESSION OF SERUM CALCIUM LEVEL}

INFUSION OF EDATHAMIL Basal gastric juice (three dogs) was collected for one hour immediately before infusion and during the last hour of the infusion. There was no consistent change in volume or $p \mathrm{H}$ (Table IX).

The infusion of histamine in four dogs was started one hour before that of edathamil and gastric juice was collected at the same time as in the previous 
TABLE VIII

EFFECT OF INTRAVENOUS CALCIUM LACTATE ON VOLUME AND TOTAL ACID OF GASTRIC JUICE SECRETED IN RESPONSE TO INFUSION OF HISTAMINE

\begin{tabular}{|c|c|c|c|c|c|c|}
\hline \multirow[t]{2}{*}{ Dog } & \multicolumn{3}{|c|}{ Volume (ml.) in One Hour } & \multicolumn{3}{|c|}{ Total Acid (mEq.) in One Hour } \\
\hline & Before Calcium & After Calcium & Change & Before Calcium & After Calcium & Change \\
\hline $\begin{array}{l}14 / 61 \\
40 / 61 \\
53 / 61 \\
54 / 61 \\
\text { Mean }\end{array}$ & $\begin{array}{r}11.6 \\
27.7 \\
5.4 \\
44.9 \\
22.4\end{array}$ & $\begin{array}{r}11 \cdot 2 \\
24 \cdot 0 \\
3 \cdot 7 \\
5 \cdot 5 \\
11 \cdot 1\end{array}$ & $\begin{array}{l}-0.4(3 \%) \\
-3.7(13 \%) \\
-1.7(31 \%) \\
-39.4(88 \%) \\
-11.3(34 \%)\end{array}$ & $\begin{array}{l}1 \cdot 8 \\
3 \cdot 1 \\
0 \cdot 5 \\
5 \cdot 7 \\
2 \cdot 8\end{array}$ & $\begin{array}{l}1 \cdot 7 \\
2 \cdot 8 \\
0 \cdot 2 \\
0 \cdot 5 \\
1 \cdot 3\end{array}$ & $\begin{array}{l}-0.1(6 \%) \\
-0.3(10 \%) \\
-0.3(60 \%) \\
-5.2(91 \%) \\
-1.5(42 \%)\end{array}$ \\
\hline
\end{tabular}

Statistical Analyses

Volume $\quad t$ (paired data) $=1 \cdot 2 ; D$ of $F=3 ; 0.4>P>0.3$

Total acid $\quad t$ (paired data) $=1 \cdot 2 ; D$ of $F=3 ; 0.4>P>0.3$

TABLE IX

EFFECT OF EDATHAMIL ON VOLUME AND $p H$ OF BASAL GASTRIC JUICE

\begin{tabular}{|c|c|c|c|c|c|c|}
\hline \multirow[t]{2}{*}{ Dog } & \multicolumn{3}{|c|}{ Volume (ml.) in One Hour } & \multicolumn{3}{|l|}{$\mathrm{p} H$} \\
\hline & Control & Edathamil & Change & Control & Edathamil & Change \\
\hline $\begin{array}{l}74 / 61 \\
15 / 62 \\
28 / 62 \\
\text { Mean }\end{array}$ & $\begin{array}{l}1.6 \\
1.3 \\
2.9 \\
1.93\end{array}$ & $\begin{array}{l}1 \cdot 2 \\
1 \cdot 5 \\
3 \cdot 3 \\
2 \cdot 00\end{array}$ & $\begin{array}{l}-0.4(-25 \%) \\
+0.2(+15 \%) \\
+0.4(+14 \%) \\
+0.06(+1 \%)\end{array}$ & $\begin{array}{l}8 \cdot 1 \\
6 \cdot 8 \\
7 \cdot 7 \\
7 \cdot 5\end{array}$ & $\begin{array}{l}8 \cdot 3 \\
7 \cdot 0 \\
6 \cdot 9 \\
7 \cdot 4\end{array}$ & $\begin{array}{l}+0.2 \\
+0.2 \\
-0.8 \\
-0.1\end{array}$ \\
\hline
\end{tabular}

Mean changes not statistically significant

TABLE X

EFFECT OF EDATHAMIL ON VOLUME AND TOTAL ACID OF GASTRIC JUICE SECRETED IN RESPONSE TO INFUSIONS OF HISTAMINE

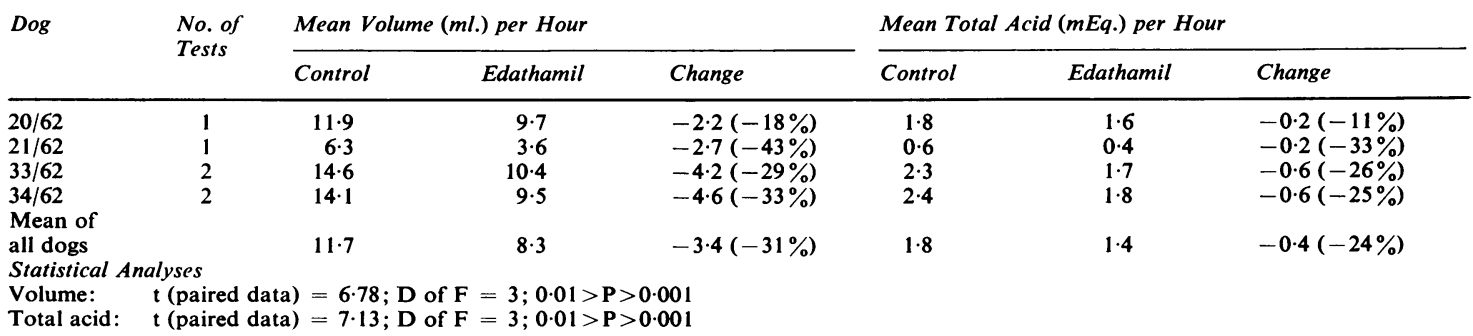

TABLE XI

EFFECT OF THYROPARATHYROIDECTOMY (WITH THYROXINE REPLACEMENT) ON VOLUME AND $p$ H OF BASAL GASTRIC JUICE Dog No. of Observations Mean Volume (ml.) per Four Hours pH Proportion of Days

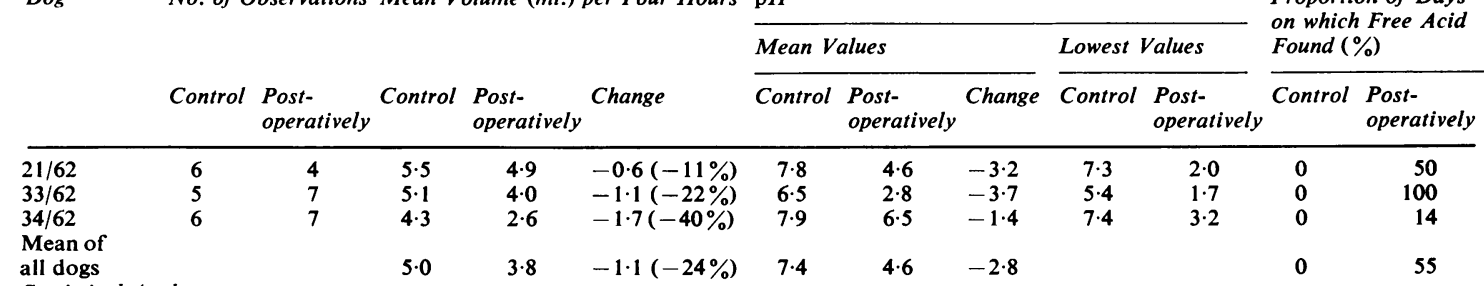

Statistical Analyses

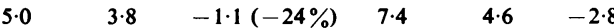

Volume $t$ (paired data) $=3.55 ; \mathbf{D}$ of $\mathbf{F}=2 ; 0.1>\mathbf{P}>0.05$

$\quad \mathrm{pH} \quad \mathrm{t}$ (paired data) $=3.96 ; \mathrm{D}$ of $\mathrm{F}=2 ; 0.1>\mathrm{P}>0.05$

experiment (Table $\mathrm{X}$ ). The volume and total acid of the secretion were reduced appreciably in all the dogs.

THYROPARATHYROIDECTOMY (WITH THYROXINE REPLACEMENT) Basal secretion (three dogs) was collected several times before and after operation. The volume and the $p \mathrm{H}$ fell appreciably in all
(Table XI), although the mean change for all the dogs was not quite significant. Free acid was found in the gastric juice of all three dogs after operation.

Standard histamine tests (three dogs) were performed several times both before and after operation. The volume and the total acid were increased greatly in two dogs and slightly in the third (Table XII). 
TABLE XII

EFFECT OF THYROPARATHYROIDECTOMY (WITH THYROXINE REPLACEMENT) ON VOLUME AND TOTAL ACID OF GASTRIC JUICE SECRETED IN RESPONSE TO SINGLE INJECTIONS OF HISTAMINE

\begin{tabular}{|c|c|c|c|c|c|c|c|c|}
\hline \multirow[t]{2}{*}{ Dog } & \multicolumn{2}{|c|}{ No. of Observations } & \multicolumn{3}{|c|}{ Mean Volume $(\mathrm{ml}$.$) per Half Hour$} & \multicolumn{3}{|c|}{ Mean Total Acid (mEq.) per Half Hour } \\
\hline & Control & $\begin{array}{l}\text { Post } \\
\text { operatively }\end{array}$ & Control & $\begin{array}{l}\text { Post- } \\
\text { operatively }\end{array}$ & Change & Control & $\begin{array}{l}\text { Post- } \\
\text { operatively }\end{array}$ & Change \\
\hline $\begin{array}{l}21 / 62 \\
33 / 62 \\
34 / 62 \\
\text { Mean for }\end{array}$ & $\begin{array}{l}6 \\
3 \\
6\end{array}$ & $\begin{array}{l}3 \\
5 \\
6\end{array}$ & $\begin{array}{l}2 \cdot 3 \\
3 \cdot 3 \\
6 \cdot 3\end{array}$ & $\begin{array}{l}7 \cdot 8 \\
8 \cdot 5 \\
6 \cdot 5\end{array}$ & $\begin{array}{l}+5.5(+240 \%) \\
+5.2(+158 \%) \\
+0.2(+3 \%)\end{array}$ & $\begin{array}{l}0.27 \\
0.39 \\
0.85\end{array}$ & $\begin{array}{l}0.90 \\
1.24 \\
0.92\end{array}$ & $\begin{array}{l}+0.63(+234 \%) \\
+0.85(+228 \%) \\
+0.07(+8 \%)\end{array}$ \\
\hline
\end{tabular}

Statistical Analyses
Volume $\quad t=2 \cdot 715 ; D$ of $F=4 ; 0.1>P>0.05$

Total acid $t=3.61 \quad D$ of $F=4 ; 0.05>P>0.02$

\section{DISCUSSION}

The finding of a high basal secretion of acid in some patients with primary hyperparathyroidism and the slight (or absent) increases in augmented histamine secretion suggest that the parietal cells are being stimulated but that their number is affected little if at all. The high basal secretion provides a possible explanation for the increased incidence of duodenal ulceration. The fall in basal secretion after parathyroidectomy probably accounts for the fact that some patients are relieved of their duodenal ulcers after operation.

Our findings in dogs are summarized in Table XIII and may be compared with those published previously (Table I). We have found, as some others have,

\section{TABLE XIII}

SUMMARY OF PRESENT FINDINGS IN DOGS WITH SEPARATED (HEIDENHAIN) POUCHES

\begin{tabular}{ll} 
Basal Juice & $\begin{array}{l}\text { Histamine-induced } \\
\text { Secretion of Acid }\end{array}$ \\
\cline { 2 - 3 } & Volume Acid
\end{tabular}

\begin{tabular}{llll}
\hline Elevation of serum calcium & & & \\
$\quad$ Parathormone & 0 & + & 0 \\
Calcium & - & 0 & $(-)$ \\
$\begin{array}{l}\text { Vitamin D } \\
\begin{array}{l}\text { Depression of serum calcium } \\
\text { Edathamil }\end{array}\end{array}$ & 0 & + & $(-)$ \\
$\begin{array}{l}\text { Parathyroidectomy } \\
+=\text { stimulation, }-=\text { depression, } 0=\text { no effect }\end{array}$ & $+(-)$ \\
Brackets indicate suggestive, but not significant, evidence.
\end{tabular}

that parathormone is capable of stimulating the parietal or acid component of gastric juice. The basal juice in separated pouches (without vagal stimulation), however, does not seem to have been studied before. The effect is definite, but inconstant and fleeting, and we have failed to produce a state of chronic hyperparathyroidism. Like others we have found that histamine-induced secretion is not augmented by parathormone, but we have not found it to be depressed. Vitamin D produced changes similar to those of parathormone on basal juice, except that the effect developed more slowly and persisted longer. It tended to depress histamineinduced secretion. Calcium lactate intravenously produced acute depression of the non-parietal secretion in basal juice and of histamine-induced parietal secretion. These results agree with all previous findings in animals and are the reverse of those reported in man. Clearly there is a species difference.

Acute reduction of the serum calcium by edathamil did not influence the basal secretion but depressed the histamine-induced secretion of acid. These findings are in keeping with the previously reported effects of parathyroidectomy and rickets in animals. In our hands, however, parathyroidectomy stimulated the secretion of acid and tended to depress the non-parietal component, while it augmented the effect of histamine. These results are contrary to those found by all previous workers and are hard to explain. Perhaps too much emphasis should not be placed on the behaviour of only three dogs, however consistent the results. On the other hand pouches without vagal innervation (which have not been studied before) may behave differently from those with the vagal supply intact and from intact stomachs.

It has been suggested (Donegan and Spiro, 1960) that there is a critical range of serum calcium concentrations within which gastric secretion occurs, that secretion varies directly with the calcium level within this range, and that secretion is inhibited when the concentration falls below or rises above it. The work on the isolated gastric mucosa of the frog (Gray and Adkison, 1941) certainly supports this hypothesis. In our experiments, however, we found active secretion as well as active inhibition both at very high, e.g., $18 \mathrm{mg} . / 100 \mathrm{ml}$., and at very low, e.g., $5 \mathrm{mg}$./100 ml., levels. Moreover stimulation or inhibition did not seem to depend on whether the concentration was rising or falling, or on whether it was at its peak value.

The relationships between parathormone, serum calcium, and gastric secretion are very complex and appear to depend on the species studied, the presence 
or absence of vagal innervation of the stomach, the rapidity with which the serum calcium level is altered, and probably on other factors also. Further work must take careful account of these variables.

\section{SUMMARY}

In patients with primary hyperparathyroidism the basal secretion of acid was raised but the augmented histamine secretion was essentially normal. Parathyroidectomy reduced the basal secretion. In dogs with Heidenhain pouches single and daily injections of parathormone tended to stimulate the secretion of acid in basal juice, but did so inconstantly and transiently. Daily injections of vitamin D had a similar effect. Intravenous injections of calcium lactate reduced the volume of basal juice. Depression of the serum calcium by edathamil reduced the output of acid in response to histamine while parathyroidectomy increased the secretion of acid in basal juice and after injection of histamine.

We are grateful to Dr. M. McGeown and Mr. E. Morrison for allowing us to investigate their patients. We thank Mr. H. O. Nevin, Miss M. A. Pountain, Miss O. Reid, and Mr. J. Mullan for technical assistance, Miss M. M. Scott for secretarial help, and Messrs. G. A. Smith and R. G. Wood for the diagrams. Mr. I. D. A. Johnston gave us much helpful advice and Mr. G. P. Burns gave valuable practical assistance. Messrs. Eli Lilly kindly supplied some of the parathormone.

\section{REFERENCES}

Abrams, G. D., and Baker, N. L. (1954). The cytology and secretory activity of gastric zymogenic cells after ablation of ductless glands. Gastroenterology, 27, 462-468.

Allen, J. E., and Elliott, D. W. (1961). Gastric response to induced hyperparathyroidism. Surg. Forum, 12, 285-287.

Austin, W. C., and Matthews, S. A. (1927). The effect of the parathyroid hormone on gastric secretion. II. The calcium content of gastric juice. Amer. J. Physiol., 81, 552-559.

Babbott, F. L. Jr., Johnston, J. A., and Haskins, C. H. (1923) Gastric acidity in infantile tetany. Amer. J. Dis. Child., 26, 486-501.

Babkin, B. P., Komarov, O., and Komarov, S. A. (1940). The effect of activated ergosterol and of parathyroid hormone on gastric secretion in the dog. Endocrinology, 26, 703-715.

Baron, D. N., and Bell, J. L. (1957). A simple specific titration method for serum calcium. Clin. chim. Acta, 2, 327-331.

Baron, J. H. (1963). Studies of basal and peak acid output with an augmented histamine test. Gut, 4, 136-144.

Bauer, W., Marble, A., Maddock, S. J., and Wood, J. C. (1931). The effect of irradiated ergosterol on the composition of gastric and pancreatic juices. Amer. J. med. Sci., 181, 399-413.

Blanshard, G., Arabehety, J. T., and Gray, S. J. (1959). Gastric secretion and parathyroid function in rats. Amer. J. Physiol. $196,844-846$.

Bock, O. A. A. (1962). The concepts of 'free acid' and 'total acid' of the gastric juice. Lancet, 2, 1101-1102.

Braun, H. A. van., Horne, R., Bettinger, J. C., and Bellet, S. (1955). The influence of hypocalcemia induced by sodium ethylenediamine tetraacetate on the toxicity of potassium: an experimental study. J. Lab. clin. Med., 46, 544-548.

Cantarow, A., Stewart, H. L., and Housel, E. L. (1938). Experimental acute hyperparathyroidism. II. Morphologic changes. Endocrinologv, 22, 13-27.
Chang, H. C., and Sloan, J. H. (1927). Influence of experimental hypothyroidism upon gastric secretion. Amer. J. Physiol., 80, 732-734.

Clark, E. P., and Collip, J. B. (1925). A study of the Tisdall method for the determination of blood serum calcium with a suggested modification. J. biol. Chem., 63, 461-464.

Code, C. F., Blackburn, C. M., Livermore, G. R., Jr., and Ratke, H. V. (1949). A method for quantitative determination of gastric secretory inhibition. Gastroenterology, 13, 573-588.

Collip, J. B. (1926). The parathyroid glands. Medicine (Baltimore), $5,1-57$.

Cowgill, G. R., and Rakieten, T. L. (1930). The effect of intravenous injection of calcium lactate upon gastric secretion. Amer. J. Physiol., 94, 165-169.

Donegan, W. L., and Spiro, H. M. (1960). Parathyroids and gastric secretion. Gastroenterolog. $v, 38,750-759$.

Friedman, G. A. (1918). Further studies of the influence of parathyroidectomy on the gastrointestinal mucosa of dogs and rabbits. J. med. Res., 38, 69-88.

Grant, R. (1941). The inhibition of gastric secretion by the intravenous injection of calcium salts. Amer. J. Physiol., 132, $460-466$

Gray, J. S., and Adkison, J. L. (1941). The effect of inorganic ions on gastric secretion in vitro. Amer. J. Physiol., 134, 27-31.

Herting, D. C., and Steenbock, H. (1955). Vitamin D and gastric secretion. J. Nutr., 57, 469-482.

Hueper, W. (1927). Metastatic calcifications in the organs of the dog after injections of parathyroid extract. Arch. Path. Lab. Med., 3, 14-25.

Kay, A. W. (1953). Effect of large doses of histamine on gastric secretion of $\mathrm{HCl}$. An augmented histamine test. Brit. med. J., 2, 77-80.

Keeton, R, W. (1914). The secretion of the gastric juice during parathyroid tetany. Amer. J. Physiol., 33, 25-49.

Lebedinskaia, S. (1927). Action of relative insufficiency of parathryoid glands on secretion of gastric juice. Arch. Biol. Nauk., 27, 61-75.

Lehr, D., Wajda, I., and Krukowski, M. (1958). Role of the parathryoid and adrenal cortex in experimental gastric ulcer. Fed. Proc., 17, 388.

Lewinter, P., and Spiro, H. M. (1960). Gastric chief cell hyperplasia induced by hypercalcemia. Metabolism, 9, 847-852.

McJunkin, F. A., Tweedy, W. R., and Breuhaus, H. C. (1932). The parathyroid hormone; its regulatory action on the parathyroid glands and toxic effects on the tissues of the rat. Arch. Path., 14, 649-659.

Mahfouz, M., and Koskowski, W. (1959). The effects of parentera administration of calcium on gastrointestinal secretions and hydrochloric acid formation. Arch. int. Pharmacodyn., 118, 1-11.

Nasset, E. S., and Goldsmith, D. P. J. (1961). Effect of thyroid on gastric secretion and metabolism. Amer. J. Physiol., 201, $567-570$

Neely, J. C., and Goldman, L. (1962). Effect of calciferol-induced chronic hypercalcemia on the gastric secretion from a Heidenhain pouch. Ann. Surg., 155, 406-411.

Ostrow, J. D., Blanshard, G., and Gray, S. J. (1960). Peptic ulcer in primary hyperparathyroidism. Amer. J. Med., 29, 767-779.

Rasenkow, I. P., and Savitch, V. V. (1925). Russk. fiz. Zh., 8, 107. Cited by Babkin et al. (1940).

Rogers, J., Rahe, J. M., Fawcett, G. G., and Hackett, G. S. (1915) The effects upon the gastric secretion of organ extracts. Amer. J. Physiol, 39, 345-353.

Rutishauser, E., and Majno, G. (1953). Etude des protéases osseuses et sériques; l'hyperparathyroỉdisme expérimental et ses répercutions sur la muqueuse gastrique et sur le taux des protéases sériques. Presse med., 61, 286-288.

Schiffrin, M. J. (1942). Relationship between the parathyroid and gastric glands in the dog. Amer. J. Physiol., 135, 660-669.

Sereghy, M., and Gyurkovich, T. von (1927). Experimental untersuchungen über die einwirkung des calciums auf die sekretion und motilität des magens. $Z$. ges. exp. Med., 54, 271-276.

Sun, D. C. H., Shay, H., Siplet, H., and Gruenstein, M. (1954). Effect of experimental athyroidism and hypothyroidism upon gastric secretion in the rat. Gastroenterology, 27, 189-200.

Val Dez, F. C., and Sendroy, J., Jr. (1942). The relationship between gastric acidity and calcium. Amer. J. dig. Dis., 9, 367-371.

Welbourn, R. B., and Ward, J. T. (1962). Hormones, gastric secretion, and peptic ulceration. Gastroenterology, 42, 784-787. 